\title{
Expressions of Aquaporin4, VEGFR1 and the pattern of genetic aberrations in meningiomas have no influence on the peritumoral edema
}

\author{
Stefan Linsler ${ }^{1}$, David Reuss ${ }^{2}$, Markus Klotz ${ }^{3}$, Karl-Herbert Schaefer ${ }^{3}$, J oachim Oertel ${ }^{1}$, Ralf \\ Ketter $^{1}$, Steffi Urbschat ${ }^{1}$ \\ 1. Department of Neurosurgery, Saarland University, Saar, Germany. 2. Department of Neuropathology, Heidelberg \\ University, Heidelberg, Germany. 3. University of Applied Sciences, Fachhochschule Kaiserslautern, Mikrosystemtechnik, \\ Zweibrücken, Germany.
}

Correspondence: PHD, Dr. Steffi Urbschat. Address: Saarland University, Department of Neurosurgery, 66421 Homburg/Saar, Germany. Email: steffi.urbschat@uks.eu

Received: March 11, 2015

DOI : $10.5430 /$ jst.v5n2p40

Accepted: April 27, 2015 URL: http://dx.doi.org/10.5430/jst.v5n2p40

\section{Abstract}

Objective: Despite the frequently reported assumption that VEGFR and Aquaporin4 (AQP4) expression seem to correlate with peritumoral brain edema formation in meningiomas, the molecular pathogenesis of edema formation is still elusive. Therefore, the authors analyzed meningioma edema formation in correlation to typical chromosomal deletions and the expression of VEGFR and Aquaporin4.

Methods: Tissue specimens of 69 meningiomas were obtained from surgery between 2008 and 2010. Locus specific FISH analysis detecting the chromosomes 1, 9, 14, 18 and 22 were performed. Moreover, immunoblotting was performed to detect the expression of VEGFR1 and VEGFR2. Aquaporin4 expression was investigated by ELISA. The results were correlated with the peritumoral brain edema in the preoperative MRI. Statistical analysis including Pearson correlation and multivariate statistical analysis was performed.

Results: In contrast to previous reports, a significant correlation to the brain edema in meningiomas could be identified only for VEGFR2 $(p<.01)$. Progression associated aberrations of chromosomes 1, 9, 14, 18 and 22 showed no correlation with the expression of VEGFR1, VEGFR2 and AQP4. AQP4 had nosignificant impact on brain edema formation as well.

Conclusions: The current data confirm a strong correlation of VEGFR expression with formation of peritumoral brain edema only for VEGFR2. Moreover, neither the expression of VEGFR1, nor the expression of VEGFR2 nor the expression of AQP4 did correlate with any specific chromosomal aberrations. The molecular actors which can induce a peritumoral brain edema in meningiomas remain widely unclear.

\section{Key words}

Meningioma, Peritumoral edema, VEGFR1, VEGFR2, Aquaporin4, Genetic aberration

\section{I ntroduction}

Meningiomas are mostly benign and slowly growing. They become symptomatic typically in the later decades of life. Only anaplastic meningiomas and a minority of common and intermediate type meningiomas are characterized by aggres- 
sive clinical behavior with increased risk of tumor recurrence. Meningiomas are very unusual tumors in terms of their high cytogenetic, biological, and clinical variability. Meningiomas, like other tumors, induce angiogenesis by a paracrine mechanism involving such molecules like vascular epithelial growth factor receptors (VEGFR). VEGFR expression in a given tumor is generally correlated with vascularity, and it increases with tumor grade ${ }^{[1-4]}$. Recent studies have reported on different factors influencing the peritumoral brain edema (PTBE) and particularly on the importance of VEGFR expression for the formation of PTBE in brain tumors ${ }^{[2,5-14]}$. Nowadays, at least five isoforms of the vascular epithelial growth factor (VEGF A-E) and 3 receptor subtypes (VEGFR1, VEGFR2 and VEGFR3) have been reported ${ }^{[15-18]}$. The VEGF family consists of VEGF-A (generally called VEGF), VEGF-B, VEGF-C, VEGF-D, and placental growth factor (PIGF). These peptides show different affinities to the 3 VEGF receptor subtypes: VEGFR1, VEGFR2, and VEGFR3. VEGF-A activates VEGFR1 and VEGFR2, whereas VEGF-B and PIGF bind only to VEFGR1. VEGF-C and VEGF-D only bind to VEGFR3. VEGFR1 regulates embryonic vasculogenesis negatively and is involved in tumor angiogenesis via activation of monocytes and macrophages. VEGFR2 is predominantly responsible for both embryonic vasculogenesis and tumor angiogenesis. In contrast, VEGFR3 regulates lymphangiogenesis ${ }^{[15]}$.

A second protein which may induce the brain edema is Aquaporin 4 (AQP4). AQP4 is a small integral membrane protein that can regulate brain water balance as water channel ${ }^{[19,20]}$. AQP4 is expressed in astrocyte foot processes surrounding capillaries, astrocyte processes comprising the glial limiting membrane, in ependymal cells, and in subependymal astrocytes ${ }^{[21,22]}$. The pattern of AQP4 protein expression suggests involvement in water movement into and out of the brain parenchyma. It has been reported that AQP4 is increased in some edematous brain tumors, such as astrocytomas and metastatic adenocarcinomas ${ }^{[23]}$.

Cytogenetic analyses have widely been used to understand the origin and the progression of meningiomas. About $25 \%$ of the meningiomas show monosomy 22 as the only aberration in the vast majority of cells, whereas hypodiploidy without monosomy 22 is very rare. Typically, the loss of chromosome 22 is followed by the loss of additional complete chromosomes or parts of them, in particular loss of chromosomes $1,6,10,14,18$, and $19^{[24-33]}$. The identification of pathogenetic pathways in human tumours is one of the main challenges in molecular oncology ${ }^{[28,33]}$. For many tumour types, genetic events defined by somatic chromosome alterations or gene mutations, respectively, are known to accumulate over time in the course of the disease. Based on these findings, genetic changes associated with chromosome instability are believed to play an important role in both tumorigenesis and tumor progression in meningiomas ${ }^{[28,33]}$.

However, actually little is known on the influence of AQP4 and VEGFR expression in association with chromosomal aberrations on peritumoral edema formation in meningiomas. Although meningioma are well analysed cytogenetically, there are no reports in the literature available about genetic aberrations and their context with peritumoral brain edema and expression of associated proteins. Thus, the authors initiated the presented study combining genetic and molecular biological approaches and findings in meningiomas to elucidate the still unclear incidence of peritumoral brain edema in meningiomas.

The main intention of this study was the investigation of expression of VEGFR1, VEGFR2 and AQP4, their influence on peritumorral brain edema formation and their correlation to progression associated chromosomal aberrations in meningiomas. Therefore 69 meningioma specimens were analysed to obtain reliable conclusions on the influence of chromosomal aberrations, AQP4- and VEGFR-expression on peritumoral brain edema formation.

\section{Materials and methods}

\subsection{Meningioma specimens}

A prospective study was performed on 69 specimens of meningioma patients (50 women and 19 men) operated on at the Department of Neurosurgery, University of the Saarland, between January 2008 and December 2010. Exclusion criteria 
were age under 18 years, incomplete data records and incomplete pre- and postoperative MR imaging. The average age of the overall patient population was 58.7 years ( $\mathrm{SD} \pm 13.3$ years). The average age of the female patients was 59.1 years ( $\mathrm{SD}$ \pm 12 years), average age of the male patients was 57.9 years ( $\mathrm{SD} \pm 15.9$ years).

\subsection{Localisation}

We formed the following eleven groups depending on meningioma location: convexity, parasagittal region, falx, tuberculum sellae, olfactory groove, sphenoid wing ridge, petroclival, posterior cranial fossa, tentorium and intraventricular. The classification was carried out on the basis of the preoperative CT and MRI.

\subsection{Tumor histology}

All tumors were classified according to the WHO classification of tumors of the nervous system of 2007. The 69 meningiomas comprised 49 tumors of WHO grade I (71\%), 18 tumors of WHO grade II (26\%), and 2 tumors of WHO grade III (3\%). The histological subtypes were classified and correlated to the PTBE.

\subsection{Peritumoral brain edema}

The tumor volume was calculated using the longest diameter of tumor extent from rostral to occipital in axial and the longest axial diameter in coronal T1-weighted images enhanced with Gadolinium contrast material $(0.1 \mathrm{mmol} / \mathrm{kg})$. PTBE was evaluated on T2-weighted images in the same manner (see Figure 1). The resulting volume of tumor and PTBE was approximated using the formula for a spheroid: $V=3 / 4 \pi$ abc. The relation of tumor to PTBE volume was defined as edema index $=(\mathrm{V}$ edema $+\mathrm{V}$ tumor $) /(\mathrm{V}$ tumor $)$, resulting in 1 when no edema was present as presented in several previous reports ${ }^{[2,3,35]}$.

Figure 1. T1-weighted aixial MR image with Gadolinium constrast the small tumor in the left frontal lobe (A) and in T2-weighted axial images of the same patient the huge extent of the PTBE in this case (B). The resulting volume of the tumor and the PTBE was approximated using the formula for a spheroid: $\mathrm{V}=3 / 4 \pi \mathrm{abc}$.

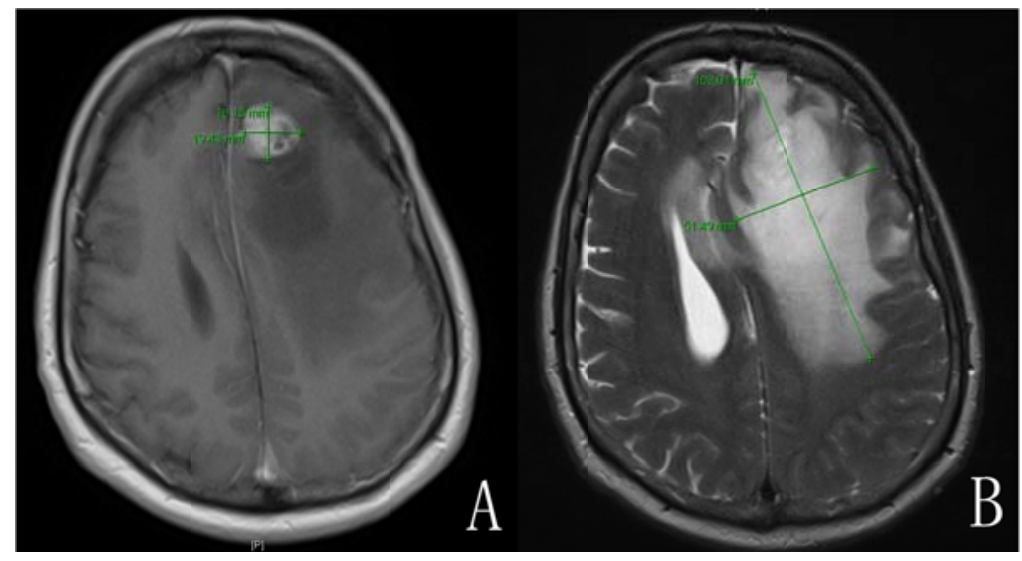

\subsection{FI SH analysis}

Tissue specimens from tumors were obtained freshly after surgery and draped on microscope slides. FISH analysis was performed using locus-specific probe for 1p36, 22q11, 14q24, 18q21 and 9p21 (Abbott, Germany and Metasystems, Germany) as described before ${ }^{[34-36]}$. At least 200 non-overlapping nuclei per sample were counted for evaluation according to the criteria of Hopman ${ }^{[37]}$, using an Olympus AX70 fluorescence microscope. At least 200 non-overlapping nuclei per sample were counted for evaluation according to the Hopman criteria ${ }^{[39]}$, using an Olympus AX70 fluorescence microscope. Cut-offs for alterations were determined by comparison with normal human lymphocytes as control samples at $10 \%$ for deletions of 1p36, 9p21, 10q23, 14q24, 18q21 and 22q11 (see Figure 2). 

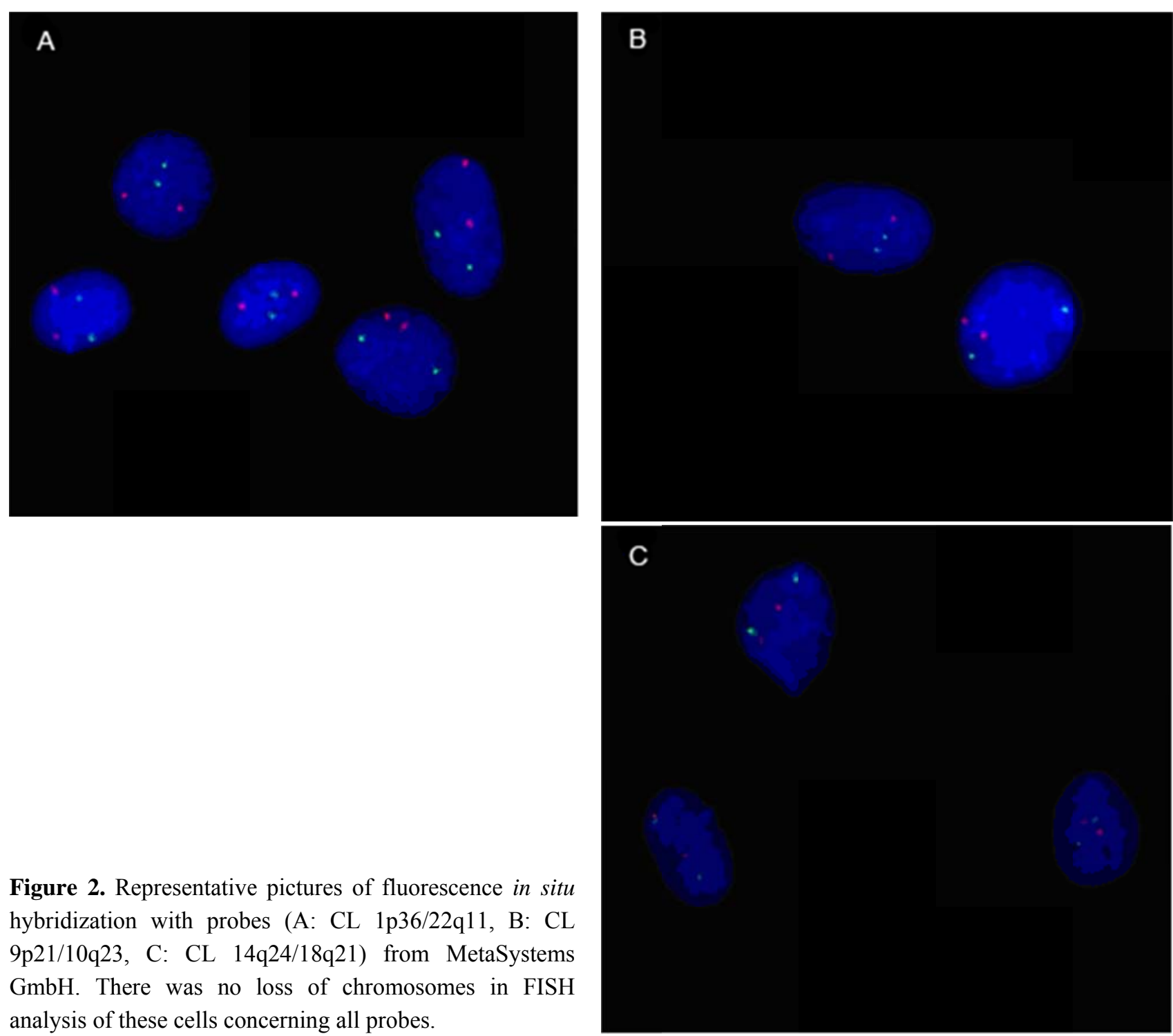

Figure 2. Representative pictures of fluorescence in situ hybridization with probes (A: CL 1p36/22q11, B: CL 9p21/10q23, C: CL 14q24/18q21) from MetaSystems $\mathrm{GmbH}$. There was no loss of chromosomes in FISH analysis of these cells concerning all probes.

\subsection{VEGFR expression}

For immunohistochemistry, a VEGFR1 antibody from R\&D Biosystems and VEGFR2 antibody from Cell Signalling was used with ultraView red (VEGFR1) or Universal DAB Detection Kit (VEGFR2) from Ventana Medical Systems for detection. The expression of VEGFR1 and VEGFR2 in meningioma tissue was classified in four categories: very strong= 3 , strong $=2$, mild $=1$ and no expression $=0$.

\subsection{Aquaporin4 expression}

ELISA was used for analysis of AQP4 expression because of better validity than immunhistochemical analyses of AQP4. Frozen samples were lyophylized overnight, the dried tissue was then homogenized (FastPrep24, MP Biomedical) and resuspended in 1:10 PBS (DPBS, Dulbecco). Protein concentration was measured (Quant-It Assay, LifeTechnologies) and concentrations adjusted to $20 \mathrm{mg} / \mathrm{ml}$. AQP4 concentrations were measured in a 10-fold dilution with a human AQP4-ELISA Kit (Hoezel, Germany) according to the manufacturer's protocol. All samples were measured in duplicate on a Genios (Tecan, Germany) plate reader at $450 \mathrm{~nm}$ and concentrations calculated with the Magellan software (Tecan, 
Germany). For further analysis, expression of AQP4 was divided in 3 subgroups: no or very low expression (0-2 ng/ml), low expression (2-4 $\mathrm{ng} / \mathrm{ml})$ and strong expression ( $>4 \mathrm{ng} / \mathrm{ml})$.

\subsection{Statistics}

The illustrations and analysis of data were performed using SPSS (SPSS, version 22.0, IBM Corporation, NY, US). Pearson correlation, Wilcoxon test and also multicariate Cox model were used to compare values of the different chromosomal aberrations, expression of VEGFR1, VEGFR2, AQP4 and PTBE and their correlation. Significance level was set at $p<.05$. All $\mathrm{p}$ values were calculated with two-sided tests. Effects in all models were quantified by hazard ratio estimates with corresponding $95 \%$ confidence intervals.

Table 1. The characterisation of our meningioma panel $(n=69)$ in detail

\begin{tabular}{|c|c|}
\hline Item & $n(N=69)$ \\
\hline \multicolumn{2}{|l|}{ Gender } \\
\hline Male & 19 \\
\hline Female & 50 \\
\hline Mean age & $58.7 \pm 13.3$ years \\
\hline \multicolumn{2}{|l|}{ WHO grading } \\
\hline WHO I & $49(71 \%)$ \\
\hline WHO II & $18(26 \%)$ \\
\hline WHO III & $2(3 \%)$ \\
\hline Tumor volume mean & $85.7 \pm 52 \mathrm{~cm}^{3}$ \\
\hline \multicolumn{2}{|l|}{ Histological subtype } \\
\hline Transitional & 26 \\
\hline Arachnoithelial & 11 \\
\hline Meningothelial & 7 \\
\hline Secretorical & 3 \\
\hline Choroid & 2 \\
\hline Fibrous & 1 \\
\hline Microzytic & 1 \\
\hline \multicolumn{2}{|c|}{ Peritumoral infiltration of tissue } \\
\hline Yes & $52 \%$ \\
\hline No & $48 \%$ \\
\hline \multicolumn{2}{|l|}{ Localisation } \\
\hline Convexity & 18 \\
\hline Parasagittal & 11 \\
\hline Tuberculum Sellae & 2 \\
\hline Olfactorial & 2 \\
\hline Sphenoid Wing & 15 \\
\hline Petroclival & 2 \\
\hline Tentorium & 5 \\
\hline Cerebellopontine Angle & 6 \\
\hline Falx & 5 \\
\hline Intraventricular & 2 \\
\hline
\end{tabular}

\section{Results}

\subsection{Histopathological findings}

Seventy-one percent (49/69) of the tumors were classified as WHO I, 26\% (18/69) as WHO II and 3\% (2/69) as WHO III. Most meningiomas were of transitional (37\%), arachnoithelial (16\%) or meningothelial (10\%) histology. Five percent 
revealed a secretory subtype. Details of the tumor cohort are demonstrated in Table 1 . The histological subtypes and also the peritumoral infiltration of the meningiomas had no significant relationship with PTBE and the molecular biological findings in multivariate analysis in all 69 meningioma specimens.

\subsection{Chromosomal aberrations}

Loss of 1 p36 was detected in 30.4\% (21/69) and loss of long arm of chromosome 22 in 29\% (20/69). Loss of 14q was detected in 13\% (9/69), loss of 18q in 7\% (5/69) and loss of 9p21 in 1.4\% (1/69). In Figure 3 loss of chromosomes in our FISH analysis is demonstrated. Loss of the short arm of chromosome 1 was significantly correlated with malignancy $(p<.05)$. Our results are in agreement with former cytogenetic investigations which indicated that the deletion of the distal part of the short arm of a chromosome 1 [1p-] is associated with progression in meningiomas ${ }^{[28,34,38]}$.

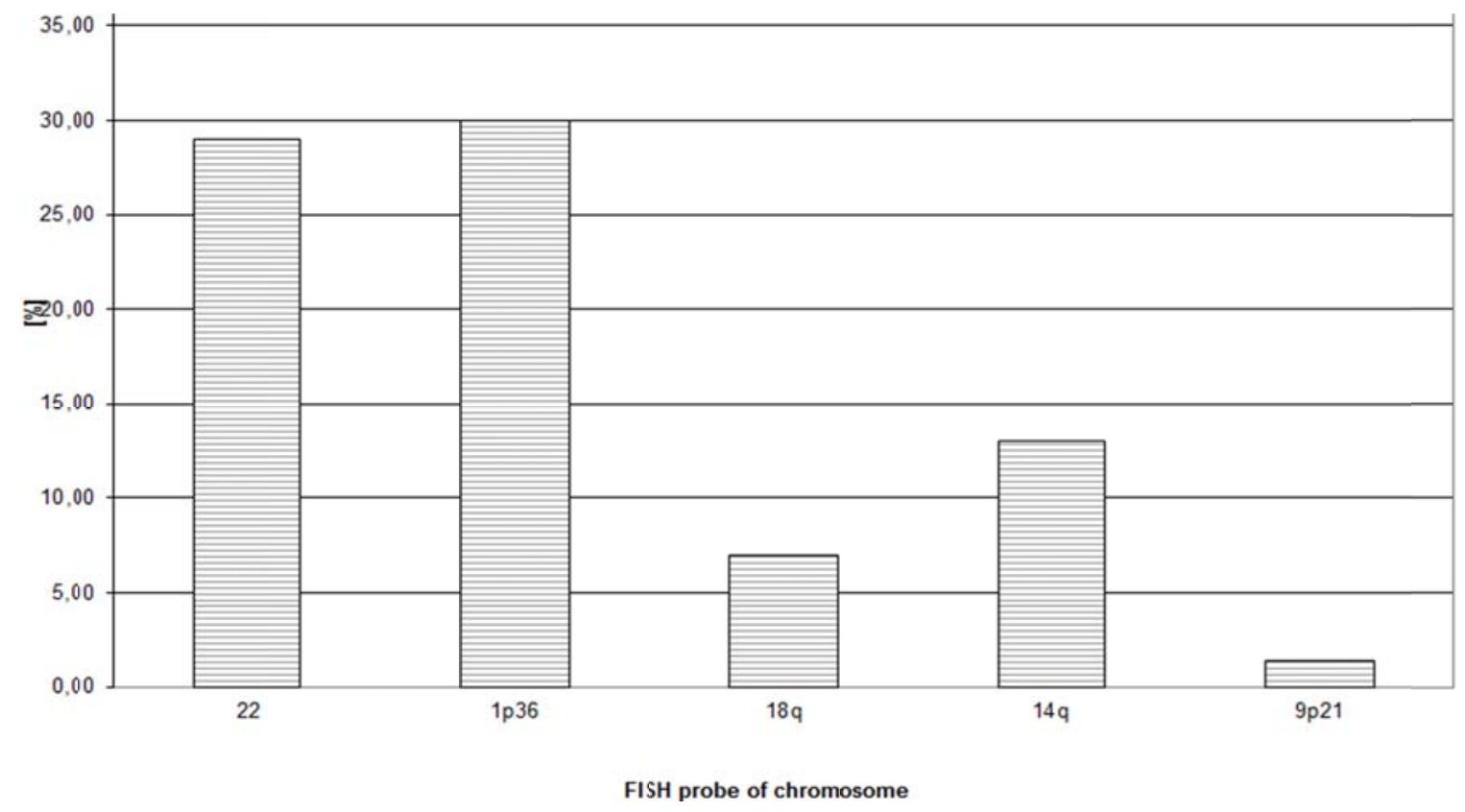

Figure 3. It presents the results of FISH analysis $(n=69)$. Most frequent loss of chromosomes in the meningioma specimens was loss of chromosome 1 p36 (30.4\%) and 22 (29\%) in our panel. Loss of 14q was detected in 13\% (9/69) and loss of $18 \mathrm{q}$ in $7 \%(5 / 69)$. Loss of $9 \mathrm{p} 21$ was very rare (1.4\%) in our panel.

\subsection{VEGFR expression}

Among the analysed meningiomas, 23\% (11/48) had a mild expression of VEGFR1, 54\% (26/48) had a strong expression and $23 \%(11 / 48)$ had a very strong expression of VEGFR1. No expression of VEGFR2 could be detected in $83 \%(44 / 53)$ of the meningiomas. Seven percent (4/53) of the meningiomas had a mild expression, 7\% (4/53) a strong and 2\% (1/53) a very strong expression of VEGFR2. In Figure 4 representative immunohistochemical stainings for VEGFR1 and VEGFR2 are shown.

WHO grade I meningiomas showed in $32 \%$ a mild expression of VEGFR 1 , in $46 \%$ a strong and in $22 \%$ a very strong expression of VEGFR1. WHO II meningiomas revealed in $28 \%$ a mild, in $57 \%$ a strong and in $14 \%$ a very strong expression of VEGFR1. Only one case of the WHO III meningiomas appeared a strong expression of VEGFR1 (data are shown in Table 2).

Also VEGFR2 was mainly expressed in WHO grade I meningiomas: $10 \%$ had a mild expression, one case a strong and one case a very strong expression of VEGFR2. In WHO II meningiomas only one case had a mild, one case a strong and one 
case a very strong expression of VEGFR2. One WHO III meningioma had a strong expression of VEGFR2 (data are shown in Table 2). In general, VEGFR2 overexpression was observed in only $17 \%$ of the meningiomas of this panel.

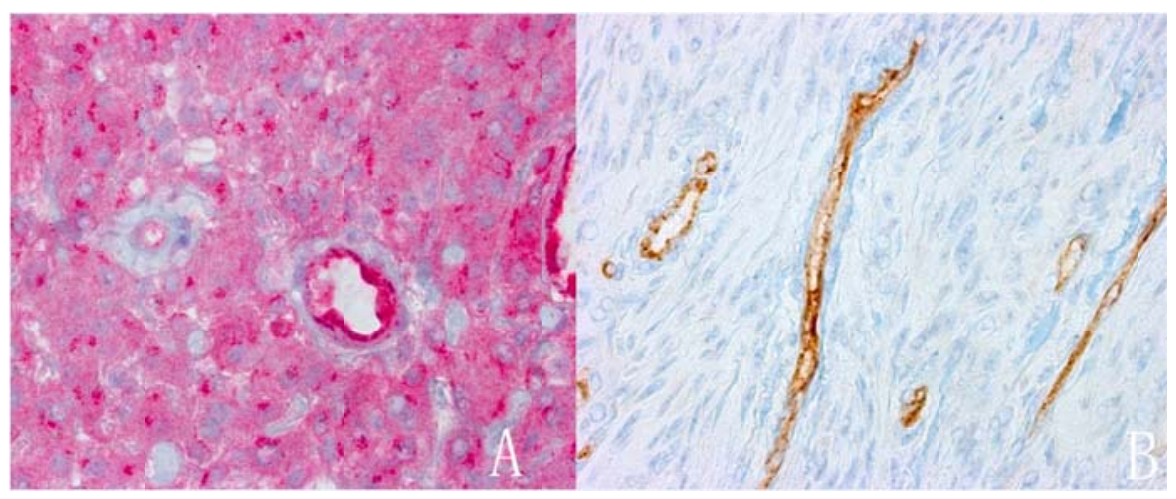

Figure 4. Exemplary slices (400× magnification) with immunostaining of VEGF1 receptors (A) and VEGF2 receptors (B). The expression of VEGFR1 and VEGFR2 in meningioma tissue was classified in four categories for the analysis.

Table 2. Expression of VEGFR1 and VEGFR2 in correlation to WHO grading.

\begin{tabular}{llll}
\hline & WHO I & WHO II & WHO III \\
\hline VEGFR1 (n=69) & & & \\
Mild expression & 16 & 5 & 1 \\
Strong expression & 22 & 10 & \\
Very strong expression & 11 & 3 & \\
VEGFR 2 (n=69) & & 1 & 1 \\
Mild expression & 5 & 1 & \\
Strong expression & 1 & 1 & \\
Very strong expression & 1 & & \\
\hline
\end{tabular}

Note. WHO grade I meningiomas showed in $32 \%$ a mild expression of VEGFR1, in $46 \%$ a strong and in $22 \%$ a very strong expression VEGFR 1 . WHO II meningiomas revealed in $28 \%$ a mild, in $57 \%$ a strong and in $14 \%$ a very strong expression of VEGFR1. VEGFR2 was mainly expressed in WHO grade I meningiomas: $10 \%$ had a mild expression. In WHO II meningiomas only one case had a mild, one case a strong and one case a very strong expression of VEGFR2. One WHO III meningioma had a strong expression of VEGFR2. In general, VEGFR2 overexpression was observed in only $17 \%$ of the meningiomas of this panel.

The expression of VEGFR1 and VEGFR2 did not correlate with any chromosomal aberrations or malignancy of meningiomas.

\subsection{Aquaporin4}

A very variable expression of Aquaporin4 was found from $0-8.5 \mathrm{ng} / \mathrm{ml}$. AQP4 did neither correlate with any chromosomal aberration nor with expression of VEGFR1 and VEGFR2. High grade meningiomas seem to have less expression of AQP4 in our analysis (see Figure 5). However the statistical impact is limited due to the low number of WHO grade 3 meningiomas.

Also all other collected factors had no effect on the expression of AQP4 in multivariate analysis.

\subsection{Peritumoral brain edema}

In our analysis of 69 meningioma patients, 28 patients appeared with PTBE causing also clinical symptoms: ten patients complained about headache, 2 patients revealed a sensory aphasia and 4 patients had a mild hemiparesis.

The relationship between tumor volume and edema volume showed a proportional trend (see Figure 6). 


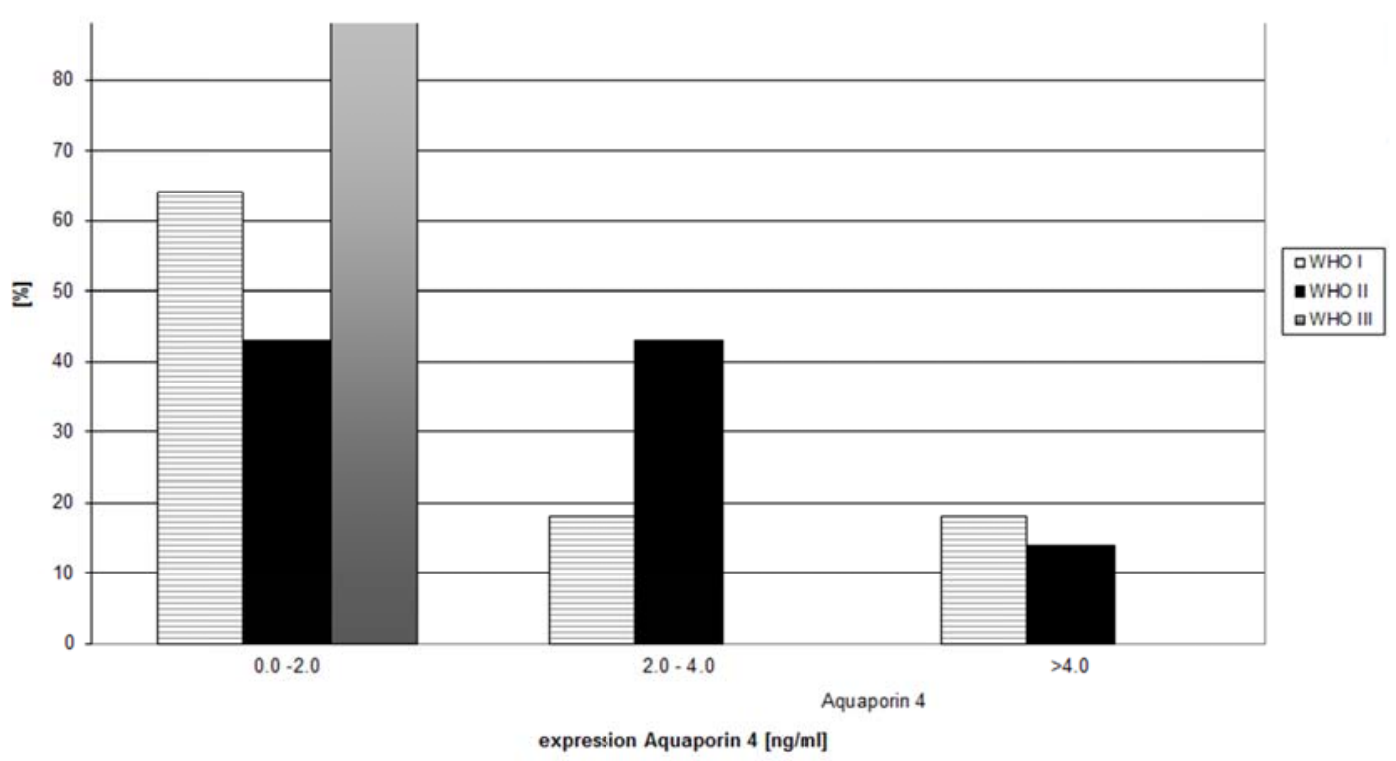

Figure 5. The relationship between WHO grading and expression of Aquaporin4. High grade meningiomas seem to have less expression of AQP4 in our analysis $(n=69)$

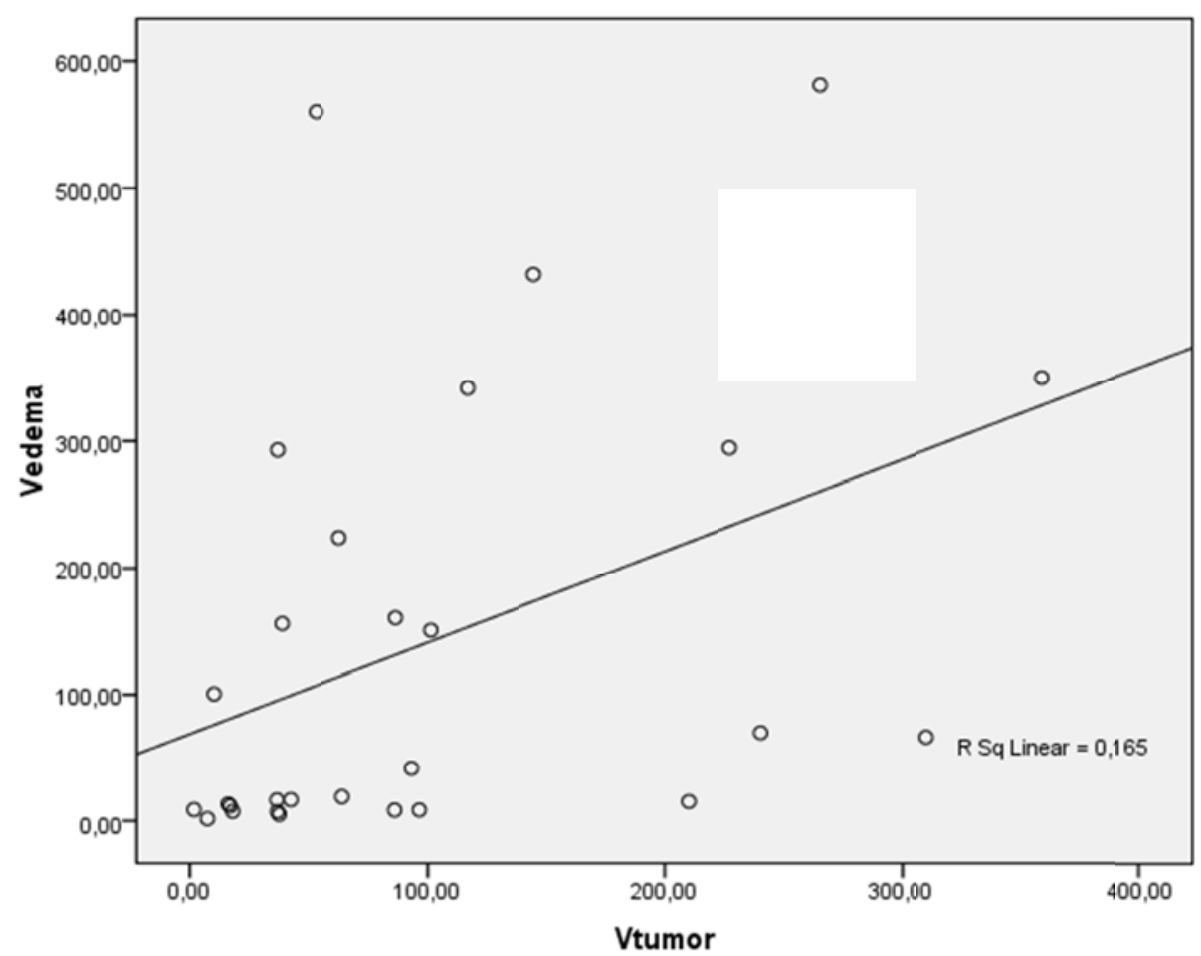

Figure 6. There was no significant correlation of tumor volume and edema volume ( $p=.28$, student $t$-test, linear correlation coefficient 0.165 ; n069)

The average volume of the 28 meningiomas accompanying PTBE was $100.6 \mathrm{~cm}^{3}$, which was larger than $70.3 \mathrm{~cm}^{3}$ as average volume of the meningiomas without PTBE. Nevertheless, the relationship between tumor volume and edema volume was non-significant ( $p=.28$, linear correlation coefficient 0.165 ). Tumor volume and even edema volume did not 
relate to VEGFR1 or Aquaporin4 expression. However, VEGFR2 expression was significantly correlated to edema volume and edema index ( $p<.01$, Pearson correlation and multivariate analysis).

Finally, we analysed the relationship of PTBE with chromosomal aberrations and WHO classification: The typical progression associated chromosomal aberrations in meningiomas, which were analysed in multivariate statistics, had no effect of edema formation. However, brain edema appeared significantly more frequently in high grade meningiomas $(p<.01)$. Still, this result has to be interpreted with care because of the low number of WHO grade 3 meningiomas in this study.

\section{Discussion}

In a panel of 69 meningioma specimens covering typical distribution of WHO grades and localisations, we assessed the brain edema in correlation to expression of VEGFR1, VEGFR2 and AQP4. Additionally, we analysed the correlation of PTBE and involved proteins with localisation, gender, WHO grading, histological subtypes, peritumoral tissue infiltration and typical progression associated chromosomal aberrations in meningiomas in multivariate analysis.

Overall, we analysed our data in a representative patient group with meningiomas concerning gender, localisation and WHO classification. It is well known that females are affected more frequently by meningiomas than males ${ }^{[28,29,39,40]}$. This observation was confirmed in our patients with a ratio of more than $3: 1$. Additionally, the results of genetic analysis in the meningioma panel correlated well to previous reports in the literature: loss of $1 \mathrm{p} 36$ was significantly correlated with higher WHO grades $(p<.05)$. This result is in accordance with previous reports about correlations of progression behaviour with chromosomal deletions in meningiomas ${ }^{[26,28,31,34,36,41]}$. In a previous study Ketter et al. ${ }^{[28]}$ presented the application of a new mathematical model for tumorgenesis in meningioma which allows estimating the probability of recurrences in meningiomas depending on their genetic aberrations.

The rate of PTBE in patients with intracranial meningiomas (40.5\% in our series) ranges from $40 \%$ to $92 \%{ }^{[2,3,5,10,42,43]}$. Many anatomical factors have been analysed to determine their influence on the PTBE in previous studies. The factors include tumor size, localisation, tumor-related venous obstruction, the disappearance of the arachnoid layer between tumor and brain, tumors vascularity, especially the vascular supply from the pial-cortical arteries ${ }^{[2-5,8,10,35,42-44]}$. Also many molecular factors like VEGF and AQP4 have been analysed ${ }^{[1,7,12,13,20,23]}$. Recently, VEGF has been reported to be a potent inducer of tumor angiogenesis and vascular permeability ${ }^{[2,5,7,45,46]}$. Other authors believe that VEGF-A pathway participates in the formation of PTBE in meningiomas by inducing formation of "leaky" capillaries, resulting in secretion of VEGF-A and plasma into the peritumoral brain tissue ${ }^{[47]}$. Although some normal tissues produce VEGFR, tumor cells show a VEGFR overexpression in a high percentage ${ }^{[1,48]}$, e.g. tumor related edema was at least partly related to VEGF expression in gliomas ${ }^{[49]}$. Recent studies reported that overexpression of VEGFR in meningiomas is correlated with PTBE $^{[2,5,7]}$. In our study, $77 \%$ of the meningiomas revealed a strong or very strong overexpression of VEGFR1, these data are in line with previous studies ${ }^{[2,5,7]}$. Only in $17 \%$ appeared a strong or very strong overexpression of VEGFR2. For VEGFR1 we did not detect any influence on PTBE and the behaviour of the meningiomas. In all previous reports, the overall expression of VEGFR was correlated with PTBE and it was suggested that VEGFR expression likely induces or at least enhances the formation of PTBE ${ }^{[2,5,7,50]}$. But for the first time, our investigation could show and specify these interactions only for VEGFR2. This findings correlate well with recently published data of Baumgarten et al. who found a stronger expression of VEGFR2 in peritumoral endothelial cells than of VEGFR1 ${ }^{[51]}$.

Especially overexpression of AQP4 did not have any impact on formation of brain edema in our study, even though it has been reported that AQP4 is increased in some edematous brain tumors, such as astrocytomas and metastatic adenocarcinomas ${ }^{[23]}$. Wang et al. reported about an upregulation of VEGF and APQ4 in meningiomas with increased PTBE ${ }^{[52]}$. Nevertheless, the role of AQP4 for formation of PTBE in meningiomas remains still unclear in the recent discussion. In our analysis, we could not confirm a significant relationship of AQP4 and PTBE in meningiomas. Anyway, the pattern of 
AQP4 protein expression suggests involvement in water movement into and out of the brain parenchyma ${ }^{[53]}$ and could generally be an important factor for brain edema. PTBE was detected significantly more frequently in high grade meningiomas. The comparison of the recent studies and our results concerning the development of the PTBE and the analysed proteins is shown in Table 3 in detail.

Table 3. The significance of correlation of the peritumoral brain edema and VEGF, AQP4 and genetic aberrations in previous studies available in the literature in comparison to our analysis

\begin{tabular}{|c|c|c|c|c|c|}
\hline & Otsuka S. et al. ${ }^{[2]}$ & Goldman C. et. al. ${ }^{[7]}$ & Wang $P$. et al ${ }^{[52]}$ & Schmid S. et al. ${ }^{[50]}$ & Our data \\
\hline $\begin{array}{l}\text { Correlation } \\
\text { VEGFR and } \\
\text { PTBE }\end{array}$ & $\begin{array}{l}\text { Positive } \\
\text { correlation }\end{array}$ & Positive correlation & $\begin{array}{l}\text { Positive } \\
\text { correlation }\end{array}$ & Positive correlation & -- \\
\hline $\begin{array}{l}\text { Correlation } \\
\text { VEGFR1 and } \\
\text { PTBE }\end{array}$ & $\begin{array}{l}\text { No differention } \\
\text { between VEGFR1 } \\
\text { and VEGFR2 }\end{array}$ & $\begin{array}{l}\text { No differention } \\
\text { between VEGFR1 and } \\
\text { VEGFR2 }\end{array}$ & $\begin{array}{l}\text { No differention } \\
\text { between VEGFR1 } \\
\text { and VEGFR2 }\end{array}$ & $\begin{array}{l}\text { No differention } \\
\text { between VEGFR1 and } \\
\text { VEGFR2 }\end{array}$ & No correlation \\
\hline $\begin{array}{l}\text { Correlation } \\
\text { VEGFR2 and } \\
\text { PTBE }\end{array}$ & $\begin{array}{l}\text { No differention } \\
\text { between VEGFR1 } \\
\text { and VEGFR2 }\end{array}$ & $\begin{array}{l}\text { No differention } \\
\text { between VEGFR1 and } \\
\text { VEGFR2 }\end{array}$ & $\begin{array}{l}\text { No differention } \\
\text { between VEGFR1 } \\
\text { and VEGFR2 }\end{array}$ & $\begin{array}{l}\text { No differention } \\
\text { between VEGFR1 and } \\
\text { VEGFR2 }\end{array}$ & $\begin{array}{l}\text { Positive } \\
\text { correlation }\end{array}$ \\
\hline $\begin{array}{l}\text { Correlation } \\
\text { AQP4 and } \\
\text { PTBE }\end{array}$ & No data & No data & $\begin{array}{l}\text { Debatable positive } \\
\text { correlation }\end{array}$ & No data & No correlation \\
\hline $\begin{array}{l}\text { Correlation } \\
\text { genetic } \\
\text { aberrations and } \\
\text { PTBE }\end{array}$ & No data & No data & No data & No data & No correlation \\
\hline $\begin{array}{l}\text { Correlation } \\
\text { WHO grading } \\
\text { and PTBE }\end{array}$ & $\begin{array}{l}\text { More PTBE in } \\
\text { high grade } \\
\text { meningiomas }\end{array}$ & No data & $\begin{array}{l}\text { More PTBE in } \\
\text { high grade } \\
\text { meningiomas }\end{array}$ & No data & $\begin{array}{l}\text { More PTBE in } \\
\text { high grade } \\
\text { meningiomas }\end{array}$ \\
\hline
\end{tabular}

Finally, expression of these proteins and expression of the PTBE had no correlation to the established progression associated - genetic aberrations in our panel. However, we could demonstrate the importance of genetic aberrations of the distal part of the short arm of a chromosome 1 [1p-] once again. In previous reports the loss of the short arm of chromosome 1 was associated with progression in meningiomas ${ }^{[28,34,38]}$, also.

In conclusion we analysed the expression of VEGFR1, VEGFR2 and AQP4 in contest to chromosomal aberrations and PTBE. Our presented data give evidence that only the expression of VEGFR2 is positively correlated with the appearance of brain edema. Findings of recent studies highlighting the impact of VEGF and AQP4 of PTBE could not be confirmed in our analysis at the same level. These results are independent of WHO grading, histological subtype, localization, gender and progression associated chromosomal aberrations in meningiomas.

\section{Competing interests statement}

The authors declare that they have no competing financial interests.

\section{Acknowlegement}

We thank Mrs Hoffmann for the technical support and Prof. Dr. med. K.D. Zang for very helpful discussion and editing support. 


\section{References}

[1] Senger DR, Van de Water L, Brown LF, et al. Vascular permeability factor (VPF, VEGF) in tumor biology. Cancer metastasis reviews. Sep 1993; 12(3-4): 303-324. PMid:8281615. http://dx.doi.org/10.1007/BF00665960

[2] Otsuka S, Tamiya T, Ono Y, et al. The relationship between peritumoral brain edema and the expression of vascular endothelial growth factor and its receptors in intracranial meningiomas. Journal of neuro-oncology. Dec 2004; 70(3): 349-357. PMid:15662977. http://dx.doi.org/10.1007/s11060-004-9164-4

[3] Bitzer M, Wockel L, Morgalla M, et al. Peritumoural brain oedema in intracranial meningiomas: influence of tumour size, location and histology. Acta neurochirurgica. 1997; 139(12): 1136-1142. PMid:9479419. http://dx.doi.org/10.1007/BF01410973

[4] Kim BW, Kim MS, Kim SW, et al. Peritumoral brain edema in meningiomas: correlation of radiologic and pathologic features. Journal of Korean Neurosurgical Society. 2011 Jan; 49(1): 26-30.

[5] Bitzer M, Wockel L, Luft AR, et al. The importance of pial blood supply to the development of peritumoral brain edema in meningiomas. Journal of neurosurgery. Sep 1997; 87(3): 368-373. PMid:9285600. http://dx.doi.org/10.3171/jns.1997.87.3.0368

[6] Brandis A, Mirzai S, Tatagiba M, et al. Immunohistochemical detection of female sex hormone receptors in meningiomas: correlation with clinical and histological features. Neurosurgery. Aug 1993; 33(2): 212-217; discussion 217-218. PMid:8367042. http://dx.doi.org/10.1227/00006123-199308000-00005

[7] Goldman CK, Bharara S, Palmer CA, et al. Brain edema in meningiomas is associated with increased vascular endothelial growth factor expression. Neurosurgery. Jun 1997; 40(6): 1269-1277. PMid:9179901.

http://dx.doi.org/10.1097/00006123-199706000-00029

[8] Hiyama H, Kubo O, Tajika Y, et al. Meningiomas associated with peritumoural venous stasis: three types on cerebral angiogram. Acta neurochirurgica. 1994; 129(1-2): 31-38. http://dx.doi.org/10.1007/BF01400870

[9] Kalkanis SN, Carroll RS, Zhang J, et al. Correlation of vascular endothelial growth factor messenger RNA expression with peritumoral vasogenic cerebral edema in meningiomas. Journal of neurosurgery. Dec 1996; 85(6): 1095-1101. PMid:8929501. http://dx.doi.org/10.3171/jns.1996.85.6.1095

[10] Lobato RD, Alday R, Gomez PA, et al. Brain oedema in patients with intracranial meningioma. Correlation between clinical, radiological, and histological factors and the presence and intensity of oedema. Acta neurochirurgica. 1996; 138(5): 485-493; discussion 493-484.

[11] Donnini S, Machein MR, Plate KH, et al. Expression and localization of placenta growth factor and PlGF receptors in human meningiomas. The Journal of pathology. Sep 1999; 189(1): 66-71. http://dx.doi.org/10.1002/(SICI)1096-9896(199909)189:1<66::AID-PATH390>3.0.CO;2-X

[12] Machein MR, Plate KH. VEGF in brain tumors. Journal of neuro-oncology. Oct-Nov 2000; 50(1-2): 109-120. PMid:11245271. http://dx.doi.org/10.1023/A:1006416003964

[13] Yoshioka H, Hama S, Taniguchi E, et al. Peritumoral brain edema associated with meningioma: influence of vascular endothelial growth factor expression and vascular blood supply. Cancer. Feb 15 1999; 85(4): 936-944. http://dx.doi.org/10.1002/(SICI)1097-0142(19990215)85:4<936::AID-CNCR23>3.0.CO;2-J

[14] Preusser M, Hassler M, Birner P, et al. Microvascularization and expression of VEGF and its receptors in recurring meningiomas: pathobiological data in favor of anti-angiogenic therapy approaches. Clinical neuropathology. May 15. http://dx.doi.org/10.5414/np300488

[15] Takahashi S. Vascular endothelial growth factor (VEGF), VEGF receptors and their inhibitors for antiangiogenic tumor therapy. Biological \& pharmaceutical bulletin. 2011; 34(12): 1785-1788.

[16] Grimmond S, Lagercrantz J, Drinkwater C, et al. Cloning and characterization of a novel human gene related to vascular endothelial growth factor. Genome research. Feb 1996; 6(2): 124-131. PMid:8919691. http://dx.doi.org/10.1101/gr.6.2.124

[17] Joukov V, Pajusola K, Kaipainen A, et al. A novel vascular endothelial growth factor, VEGF-C, is a ligand for the Flt4 (VEGFR-3) and KDR (VEGFR-2) receptor tyrosine kinases. The EMBO journal. Apr 1 1996; 15(7): 1751. PMid:8612600.

[18] Olofsson B, Pajusola K, Kaipainen A, et al. Vascular endothelial growth factor B, a novel growth factor for endothelial cells. Proceedings of the National Academy of Sciences of the United States of America. Mar 19 1996; 93(6): 2576-2581. PMid:8637916. http://dx.doi.org/10.1073/pnas.93.6.2576

[19] Jung JS, Preston GM, Smith BL, et al. Molecular structure of the water channel through aquaporin CHIP. The hourglass model. The Journal of biological chemistry. May 20 1994; 269(20): 14648-14654. PMid:7514176.

[20] Tait MJ, Saadoun S, Bell BA, et al. Water movements in the brain: role of aquaporins. Trends in neurosciences. Jan 2008; 31(1): 37-43. PMid:18054802. http://dx.doi.org/10.1016/j.tins.2007.11.003

[21] Nielsen S, Nagelhus EA, Amiry-Moghaddam M, et al. Specialized membrane domains for water transport in glial cells: high-resolution immunogold cytochemistry of aquaporin-4 in rat brain. J Neurosci. Jan 1 1997; 17(1): 171-180. PMid:8987746. 
[22] Rash JE, Yasumura T, Hudson CS, et al. Direct immunogold labeling of aquaporin-4 in square arrays of astrocyte and ependymocyte plasma membranes in rat brain and spinal cord. Proceedings of the National Academy of Sciences of the United States of America. Sep 29 1998; 95(20): 11981-11986. PMid:9751776. http://dx.doi.org/10.1073/pnas.95.20.11981

[23] Saadoun S, Papadopoulos MC, Davies DC, et al. Aquaporin-4 expression is increased in oedematous human brain tumours. Journal of neurology, neurosurgery, and psychiatry. Feb 2002; 72(2): 262-265. PMid:11796780. http://dx.doi.org/10.1136/jnnp.72.2.262

[24] Bello MJ, de Campos JM, Kusak ME, et al. Allelic loss at 1p is associated with tumor progression of meningiomas. Genes, chromosomes \& cancer. Apr 1994; 9(4): 296-298. PMid:7519053. http://dx.doi.org/10.1002/gcc.2870090411

[25] Henn W, Cremerius U, Heide G, et al. Monosomy $1 p$ is correlated with enhanced in vivo glucose metabolism in meningiomas. Cancer genetics and cytogenetics. Feb 1995; 79(2): 144-148. http://dx.doi.org/10.1016/0165-4608(94)00135-X

[26] Ketter R, Henn W, Niedermayer I, et al. Predictive value of progression-associated chromosomal aberrations for the prognosis of meningiomas: a retrospective study of 198 cases. Journal of neurosurgery. Oct 2001; 95(4): 601-607. PMid:11596954. http://dx.doi.org/10.3171/jns.2001.95.4.0601

[27] Ketter R, Kim YJ, Storck S, et al. Hyperdiploidy defines a distinct cytogenetic entity of meningiomas. Journal of neuro-oncology. Jun 2007; 83(2): 213-221. PMid:17225936. http://dx.doi.org/10.1007/s11060-006-9318-7

[28] Ketter R, Urbschat S, Henn W, et al. Application of oncogenetic trees mixtures as a biostatistical model of the clonal cytogenetic evolution of meningiomas. International journal of cancer. Oct 1 2007; 121(7): 1473-1480. PMid:17557299. http://dx.doi.org/10.1002/ijc.22855

[29] Muller P, Henn W, Niedermayer I, et al. Deletion of chromosome 1p and loss of expression of alkaline phosphatase indicate progression of meningiomas. Clin Cancer Res. Nov 1999; 5(11): 3569-3577. PMid:10589773.

[30] Niedermayer I, Feiden W, Henn W, et al. Loss of alkaline phosphatase activity in meningiomas: a rapid histochemical technique indicating progression-associated deletion of a putative tumor suppressor gene on the distal part of the short arm of chromosome 1. Journal of neuropathology and experimental neurology. Aug 1997; 56(8): 879-886. PMid:9258258. http://dx.doi.org/10.1097/00005072-199708000-00006

[31] Simon M, von Deimling A, Larson JJ, et al. Allelic losses on chromosomes 14, 10, and 1 in atypical and malignant meningiomas: a genetic model of meningioma progression. Cancer research. Oct 15 1995; 55(20): 4696-4701. PMid:7553651.

[32] Urbschat S, Rahnenfuhrer J, Henn W, et al. Clonal cytogenetic progression within intratumorally heterogeneous meningiomas predicts tumor recurrence. International journal of oncology. 2011 Dec; 39(6): 1601-1608.

[33] Zang KD. Meningioma: a cytogenetic model of a complex benign human tumor, including data on 394 karyotyped cases. Cytogenetics and cell genetics. 2001; 93(3-4): 207-220. PMid:11528114. http://dx.doi.org/10.1159/000056986

[34] Linsler S, Kraemer D, Driess C, et al. Molecular biological determinations of meningioma progression and recurrence. PloS one. 2014; 9(4): e94987. PMid:24722350. http://dx.doi.org/10.1371/journal.pone.0094987

[35] Bitzer M, Topka H, Morgalla M, et al. Tumor-related venous obstruction and development of peritumoral brain edema in meningiomas. Neurosurgery. Apr 1998; 42(4): 730-737. PMid:9574636. http://dx.doi.org/10.1097/00006123-199804000-00026

[36] Lerner C, Ketter R, Linsler S, et al. Establishment of a molecular cytogenetic analysis for native tumor tissue of meningiomas-suitable for clinical application. Molecular cytogenetics. 2014; 7(1): 12. PMid:24499596. http://dx.doi.org/10.1186/1755-8166-7-12

[37] Hopman AH, Ramaekers FC, Raap AK, et al. In situ hybridization as a tool to study numerical chromosome aberrations in solid bladder tumors. Histochemistry. 1988; 89(4): 307-316. PMid:3410743. http://dx.doi.org/10.1007/BF00500631

[38] Lerner C, Ketter R, Linsler S, et al. Establishment of a molecular cytogenetic analysis for native tumor tissue of meningiomas-suitable for clinical application. Molecular cytogenetics. 2011 Feb 5; 7(1): 12.

[39] Niedermayer I, Kolles H, Zang KD, et al. Characterization of intermediate type (WHO "atypical") meningiomas. Clinical neuropathology. Nov-Dec 1996; 15(6): 330-336. PMid:8937779.

[40] Beks JW, de Windt HL. The recurrence of supratentorial meningiomas after surgery. Acta neurochirurgica. 1988; 95(1-2): 3-5. http://dx.doi.org/10.1007/BF01793074

[41] Mawrin C, Perry A. Pathological classification and molecular genetics of meningiomas. Journal of neuro-oncology. 2011 Sep; 99(3): 379-391.

[42] Bradac GB, Ferszt R, Bender A, et al. Peritumoral edema in meningiomas. A radiological and histological study. Neuroradiology. 1986; 28(4): 304-312. PMid:3762907. http://dx.doi.org/10.1007/BF00333435

[43] Maiuri F, Gangemi M, Cirillo S, et al. Cerebral edema associated with meningiomas. Surgical neurology. Jan 1987; $27(1)$ : 64-68. http://dx.doi.org/10.1016/0090-3019(87)90109-1

[44] Kolles H, Niedermayer I, Schmitt C, et al. Triple approach for diagnosis and grading of meningiomas: histology, morphometry of Ki-67/Feulgen stainings, and cytogenetics. Acta neurochirurgica. 1995; 137(3-4): 174-181. http://dx.doi.org/10.1007/BF02187190 
[45] Samoto K, Ikezaki K, Ono M, et al. Expression of vascular endothelial growth factor and its possible relation with neovascularization in human brain tumors. Cancer research. Mar 1 1995; 55(5): 1189-1193. PMid:7532545.

[46] Yamasaki F, Yoshioka H, Hama S, et al. Recurrence of meningiomas. Cancer. Sep 1 2000; 89(5): 1102-1110. http://dx.doi.org/10.1002/1097-0142(20000901)89:5<1102::AID-CNCR20>3.0.CO;2-L

[47] Nassehi D. Intracranial meningiomas, the VEGF-A pathway, and peritumoral brain oedema. Danish medical journal. Apr 2013; 60(4): B4626. PMid:23651727.

[48] Berkman RA, Merrill MJ, Reinhold WC, et al. Expression of the vascular permeability factor/vascular endothelial growth factor gene in central nervous system neoplasms. The Journal of clinical investigation. Jan 1993; 91(1): 153-159. PMid:8380810. http://dx.doi.org/10.1172/JCI116165

[49] Yao Y, Kubota T, Sato K, et al. Prognostic value of vascular endothelial growth factor and its receptors Flt-1 and Flk-1 in astrocytic tumours. Acta neurochirurgica. 2001; 143(2): 159-166. PMid:11459088. http://dx.doi.org/10.1007/s007010170122

[50] Schmid S, Aboul-Enein F, Pfisterer W, et al. Vascular endothelial growth factor: the major factor for tumor neovascularization and edema formation in meningioma patients. Neurosurgery. Dec 2010; 67(6): 1703-1708; discussion 1708.

[51] Baumgarten P, Brokinkel B, Zinke J, et al. Expression of vascular endothelial growth factor (VEGF) and its receptors VEGFR1 and VEGFR2 in primary and recurrent WHO grade III meningiomas. Histology and histopathology. Sep 2013; $28(9)$ : $1157-1166$. PMid:23475388.

[52] Wang P, Ni RY, Chen MN, et al. Expression of aquaporin-4 in human supratentorial meningiomas with peritumoral brain edema and correlation of VEGF with edema formation. Genet Mol Res. 2011; 10(3): 2165-2171. PMid:21968684. http://dx.doi.org/10.4238/vol10-3gmr1212

[53] Papadopoulos MC, Verkman AS. Aquaporin-4 and brain edema. Pediatric nephrology (Berlin, Germany). Jun 2007; 22(6): 778-784. PMid:17347837. http://dx.doi.org/10.1007/s00467-006-0411-0 